383 Repair and Servicing of Road Vehicles Series

Levels 2 \& 3

\title{
Transmission, Chassis and Related Systems
}

AUTHOR JOHN WHIPP EDITED BY ROY BROOKS 
All rights reserved. No reproduction, copy or transmission of this publication may be made without written permission.

No paragraph of this publication may be reproduced, copied or transmitted save with written permission or in accordance with the provisions of the Copyright Designs and Patents Act 1988 or under the terms of any licence permitting limited copying issued by the Copyright Licensing Agency, 33-4 Alfred Place, London WC1E 7DP.

Any person who does any unauthorised act in relation to this publication may be liable to criminal prosecution and civil claims for damages.

\section{First published 1990}

Published by MACMILLAN EDUCATION LTD

Houndmills, Basingstoke, Hampshire RG21 2XS and London

Companies and representatives throughout the world

British Library Cataloguing in Publication Data

Whipp, J. (John)

383 Repair and servicing of road vehicles.

Levels $2 \& 3$, Transmission, chassis and related systems.

1. Motor Vehicles. Maintenance \& Repair

I. Title II. Brooks, R. (Roy), 1929-

629.287

ISBN 978-0-333-54297-2 ISBN 978-1-349-12119-9 (eBook)

DOI 10.1007/978-1-349-12119-9 


\section{Contents}

Page no.

$\begin{array}{lr}\text { Clutches } & 1 \\ \text { Manual gearboxes } & 20 \\ \text { Automatic transmission systems } & 51 \\ \text { Drive line } & 74 \\ \text { Final drive and differentials } & 85 \\ \text { Suspension } & 99 \\ \text { Steering } & 125 \\ \text { Tyres and wheels } & 141 \\ \text { Braking } & 168 \\ \text { Bodywork } & 211 \\ \text { Electrical and electronic systems } & 217 \\ \text { Lighting systems } & 235 \\ \text { Auxiliary electrical systems } & 245 \\ \text { Related studies } & 265 \\ \text { Industrial studies } & 276\end{array}$




\section{Preface}

This book, along with its companion volume, Engines and Related Systems, have been designed specifically to meet the needs of students following the City and

Guilds 383 Syllabus, Repair and Servicing of Road Vehicles, at levels 2 and 3, and those taking other similar courses.

Undoubtedly the $\mathbf{3 8 3}$ syllabus is substantially different from its predecessors. Along with the very rapid advances in motor vehicle technology, it presents particular challenges by way of interpretation and implementation. There are also problems, with the syllabus, in avoiding overlap within the various elements, units and levels.

Much careful thought and considerable experience has gone into the content and style of these pages. There are, of course, areas where the editorial team would have preferred to have tackled certain topics somewhat differently, but were constrained by syllabus requirements. Equally, however, there are some instances where desirable additional material has been included as an aid to greater understanding.

Naturally enough these books are concerned, as were their highly successful predecessors, with the classroom aspects of motor vehicle work. They do, though, help the teacher to conveniently provide a level of understanding that will enable students to achieve a confident knowledge of systems and components, and their operation in the work situation. In consequence, 
workshop tasks are not covered in fine detail. It is expected that such procedures will be taught at work or in garage practice classes. Similarly it is also expected that students will refer to appropriate workshop manuals and/or instruction sheets for the work in hand.

By a combination of such methods and proper completion of these books, a very high standard of training will be achieved. This should be fully sufficient to

satisfy examination requirements, as well as providing students with a valuable source of reference and a permanent record of their studies.

Each book is presented in a sound, logical order, with syllabus references shown for convenience. It should, though, be realised that this is not necessarily always the most appropriate teaching order, which is likely to vary considerably according to available facilities and preferences.

The editor and authors wish success to everyone who uses these books. If you have any constructive suggestions that you would care to make about them, we should be most pleased to hear from you via Macmillan Education Ltd, Basingstoke. 


\section{Acknowledgements}

The editor, author and publishers would like to thank all who helped so generously with information, assistance, illustrations and inspiration. In particular the book's principal illustrator, Harvey Dearden (previously principal lecturer in Motor Vehicle Subjects,

Moston College of Further Eduction); colleagues of the Burnley College and the North Manchester College; Andrea Whipp for her dedication in preparing the manuscript; and the persons, firms and organisations listed below. Should there be any omissions,

they are completely unintentional.

A-C Delco Division of General Motors Ltd

Alfa Romeo (Great Britain) Ltd

Austin Rover Group

Automotive Products plc

Robert Bosch Ltd

R Boughton Esq.

British Standards Institution

Castrol UK Ltd

Champion Sparking Plug Co. Ltd

Citroën UK Ltd

City \& Guilds of London Institute

Clayton Dewandre Ltd

Dunlop (SP Tyres UK Ltd)

Fiat Auto (UK) Ltd

Ford Motor Co. Ltd

Girling Ltd

Honda UK Ltd

Land Rover Ltd

Lucas Industries plc
Luminetion Ltd

MAN - Volkswagen

Metalistic Ltd

Michelin Tyre plc

Mitsubishi Motors (The Colt Car Co. Ltd)

Peugeot Talbot Motor Co. Ltd

Renault UK Ltd

Ripaults Ltd

Scania (Great Britain) Ltd

Seddon Atkinson Ltd

Suzuki Cars (GB) Ltc

Alfred Teves $\mathrm{GmbH}$

Unipart Group of Companies

VAG (United Kingdom) Ltd

Vauxhall Motor Co. Ltd

Volvo Concessionaires Ltd

Westinghouse CVB Ltd

ZF Gears (GB) Ltd 